\title{
Evaluation of subclinical liver lesions in goats by ultrasonographic and biochemical analyses*
}

\author{
Ramazan GÖNENCI ${ }^{1}$, Ramazan DURGUT ${ }^{2}$, Suat ERDOĞ $\breve{G N}^{3}$ \\ ${ }^{1}$ Mustafa Kemal University, Veterinary Faculty, Department of Surgery, Hatay; ${ }^{2}$ Mustafa Kemal University, Veterinary Faculty, \\ Department of Internal Medicine, Hatay; ${ }^{3}$ Mustafa Kemal University, Veterinary Faculty, Department of Biochemistry, Hatay
}

Summary: This study included 75 Damascus and its crossbreed goats from different age and sexes in the Hatay province. Following the history, all the animals were subjected to clinical, ultrasonographic and biochemical examinations. The clinical signs were generally normal. Ultrasonographically, parenchymal lesions in 17, biliary system abnormalities in 8 and both biliary and parenchymal abnormalities in 23 animals were detected. In these 48 goats with hepatic lesions; 26 parenchymal hyperechogenicily, 17 cysts and 10 masses of parenchyma, and 25 wall thickenings, 3 foldings and 3 sediments of gallbladder were observed alone or together. LDH levels in goats with and without hepatic lesions were higher than normal reference range, whereas ALT. ALP. AST, GGT. BUN, TP, CB. CHO, albumine and glucose concentrations were in normal reference ranges. In this study, it is concluded that lesions could be observed ultrasonographically before clinical signs and biochemical abnormalities manifest.

Key words: Biochemical analyses, goat, liver, ultrasonography

\section{Keçilerde subklinik karaciğer lezyonlarının ultrasonografik ve biyokimyasal olarak değerlendirilmesi}

Özet: Bu çalışma Hatay’ın çeşitli yerlerinden temin edilen de ğişik yaş ve cinsiyetten 75 Şam keçisi ve melezleri üzerinde yapıldı. Gerekli anamnez alındıktan sonra, bütün hayvanlar klinik, ultrasonografik ve biyokimyasal muayenelere tabi tutuidu. Klinik bulgular genellikle normal idi. Ultrasonografik olarak, hayvanlarm 17'sinde parenşimal, 8 'inde bilier sistem ve 23 'iinde de hem parenşimal hem de bilier sistem lezyonlanma birlikte rastland. Bu lezyonlu 48 keçide 26 parenşimal hiperekojenite. 17 kist, 10 kitle, 25 safra kesesi duvarunda kalınlaşma, 3 katlanma ve 3 sediment oluşumu tek başma ya da diğer lezyonlarla birlikte gözlendi. ALT. ALP, AST, GGT, BUN, TP, CB, CHO, albumin ve glukoz konsantrasyonları lezyonlu ve lezyonsuz keçilerde normal iken, sadece LDH her ikisinde de yüiksek bulundu. Bu çalışma ile karaciğer lezyonlarının klinik ve biyokimyasal anormallikler ortaya çıkmadan önce ultrasonografik olarak gözlenebileceği sonucuna varıldı.

Anahtar kelimeler: Biyokimyasal analizler, karaciğer, keçi, ultrasonografi

\section{Introduction}

Liver is highly susceptible for parenchymal, vascular and biliary system lesions. Bacterial, chemical, viral, toxic or immune-mediated insults may cause focal or diffuse hepatic abnormalities or lesions (8-10,12).

Diagnostic and prognostic use of ultrasonography is one of the most important and prominent tools for the detection and recognition of many types of focal parenchymal lesions such as cysts, hemorrhages, haematomas, abscesses, necrosis, nodular hyperplasia, granulomas and neoplasia $(3,5)$. The liver is well suited for ultrasonographic evaluation because of its large size and a uniform parenchymal appearance on ultrasound scans. On the other hand, due to the fact that ultrasonography is least valuable for recognition of diffuse forms of the disease, other diagnostic methods such as biopsy are almost necessary $(1,2,8,9,11)$.
The main indications for scanning the biliary system are to rule out extrahepatic obstruction, to detect biliary calculi, and to visualize thickening of the gallbladder wall, masses or inflammatory diseases associated with gallbladder and biliary tract. Enlargement of the hepatic veins, obstruction of the caudal vena cava by clots or masses, congenital and acquired vascular abnormalities can also be imaged $(6,7,13)$.

Hepatocyte damage may result in the release of enzymes that may indicate the hepatocyte integrity or bile excretions into the circulation or failure to produce and excrete them. The biochemical tests are useful in the assessment of hepatic functions, diagnosis and the severity of liver disease. They are also valuable diagnostic methods for defining causes of complications of hepatic insufficiency $(4,10)$. 
The aim of this study was to investigate and evaluate the subclinical focal liver lesions using ultrasonographic examination and biochemical analyses in clinically normal goats in Hatay province.

\section{Materials and Methods}

This study was carried out in 75 Damascus and its crossbreed goats from different age and sexes in Hatay province. After taking the anamnesis, they were all subjected to clinical, laboratory and ultrasound examinations. The animals were kept in stand position for ultrasound scans after general examination. A small area of their hair between last two intercostal space in the right side was clipped. In the imaging procedure, the liver was evaluated for typical signs of hepatic degeneration in size and echogenicity in order to detect focal or multifocal liver lesions. The hepatic ultrasound parameters were evaluated routinely including size, margin, echogenicity, vascularity, gallbladder and perihepatic abnormalities.

For biochemical evaluations, $10 \mathrm{ml}$ of blood samples were taken from the jugular vein, and sera were separated by centrifugation. Samples were analysed for serum alkaline phosphatase (ALP), alanine aminotransferase (ALT), aspartate aminotransferase (AST), gamma-glutamyl transferase (GGT), lactate dehydrogenase (LDH), blood urea nitrogen (BUN), albumin (Alb), total protein (TP), conjugated bilirubin (CB), triglyceride (TG), glucose and cholesterol (CHO) in AMS Autolab analyser, using Biomedical System and Audit Diagnostic kits. One-Way

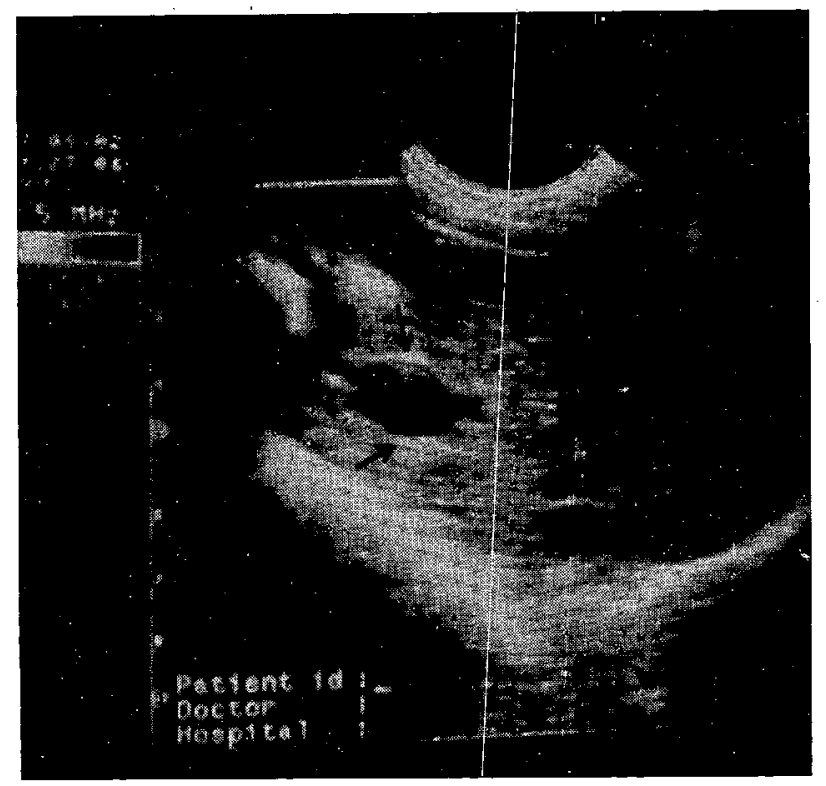

Figure 1. Ulurasonographic appearance of gallbladder wall thickening. The arrows show the gallbladder wall thickening. Note that hepatic parenchyma appears almost normal.
Anova test in SPSS programme (version 9.05) wàs used for statistical analysis.

\section{Results}

There was no signs showing thelliver disorders such as, icterus, weight lose, ascites, diarrhoea and abdominal pain over the livers on clinical / examination. Few abscesses were identified in 20 animals, which were thought to be caused by caseous lymphadenitis that they experienced previously, and the majority of these animals had pneumonia.

On ultrasonographic examination, most of the animals $(n=48)$ had hepatic lesions including parenchymal, biliary or both, and the rest of the animals (27) appeared to be normal. Only parenchymal lesions were seen in 17 goats including parenchymal hyperechógenicity, cysts and masses, the frequency of which were 10, 7, and 4 , respectively. Parenchymal tissue with hyperechogenicity had an increased echogenicity, which either focal or diffuse. Only biliary system abnormalities were seen in 8 goats, including thickening, folding and sediment of gallbladder wall, the frequency of which were 6,1 and 1 , respectively. The appearance of the gallbladders was anechoic, having thick walls with hyperechogenicity (Figure 1). On the other hand, the 23 goats had both parenchymal and biliary lesions together (Figure 2).

The liver of 17 goats had cysts with anechoic architecture and a thin wall (Figure 3). The longitudinal scans of goats showed 10 multifocal hypoechoic masses

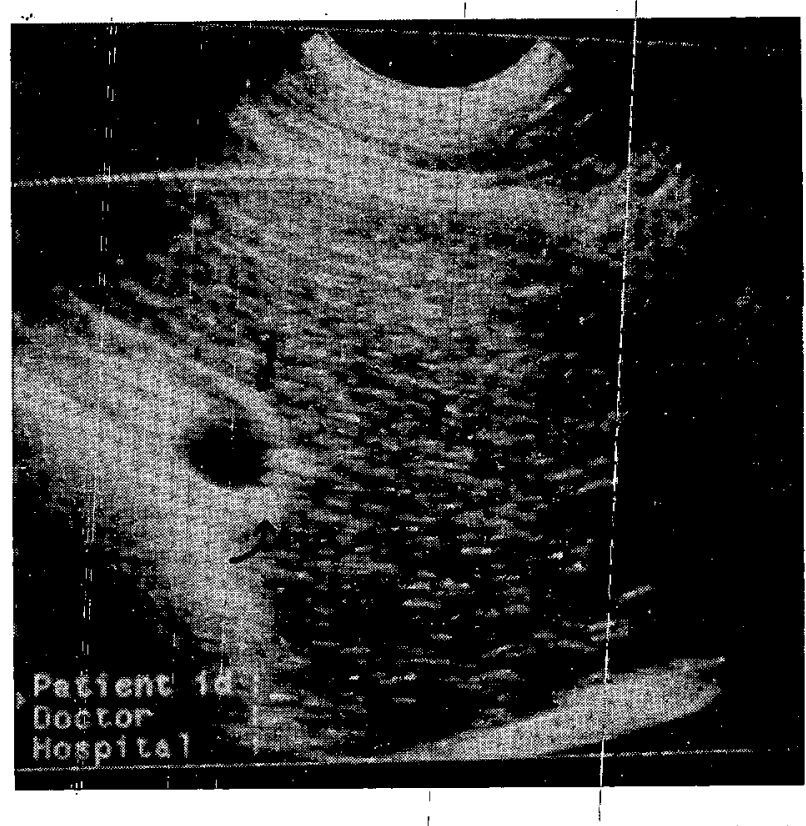

Figure 2. On ultrasonography, a gallbladder wall thickening is seen, which is shown by the curyed arrows. The region shown by the arrow heads is diffuse hyperechoic liver parenchyma. 


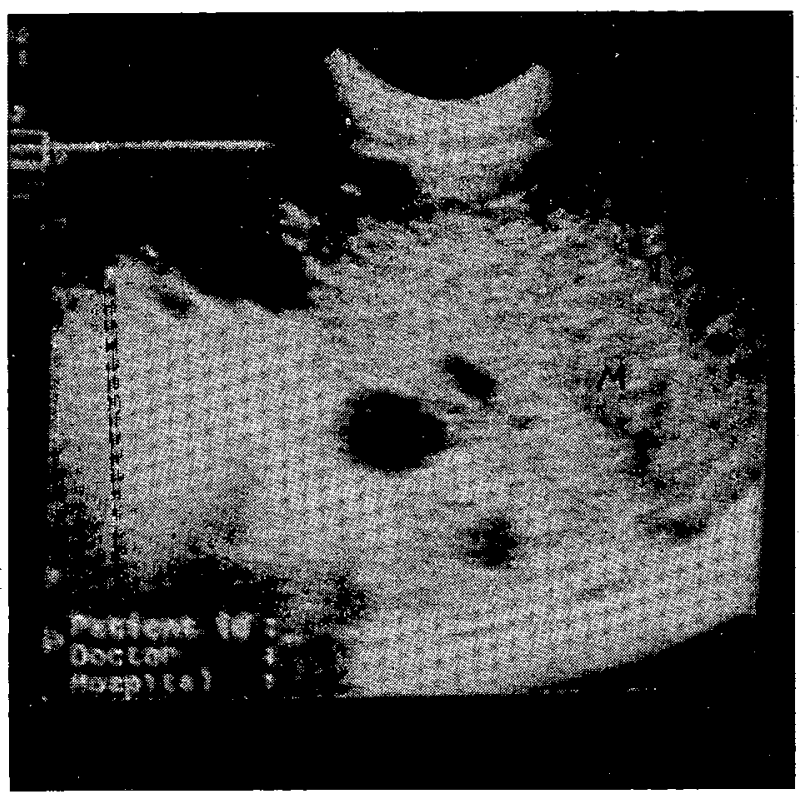

Figure 3. Appeatrances of a cyst $(C)$ and a mass $(M)$ with a diffuse and increased hepatic echogenicity.

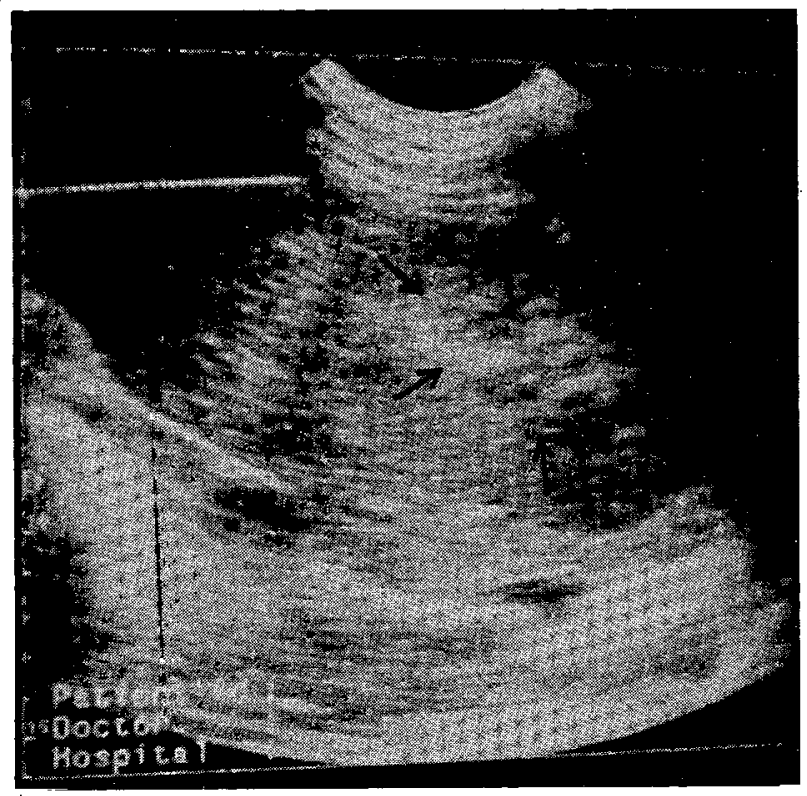

Figure 4. An egg-shaped mass shown by the arrows with increased hepatic echogenicity.

in parenchyma, which are rounded and with thin and well-defined or irregular walls. Hypoechoic masses were differentiated from the gallbladder by their location, the absence of contraction and gallbladder neck (Figure 4). Folding of the gallbladder on itself was also detected in 3 goats which was differentiated from a mirror-image artifact because there is no diaphragm between two gallbladders (Figure 5). Gallbladder lumen filled with sediment was apparent and agitated with back-and forth transducer pressure in 7 goats. All the ultrasonographic lesions were summarized in Table 1.

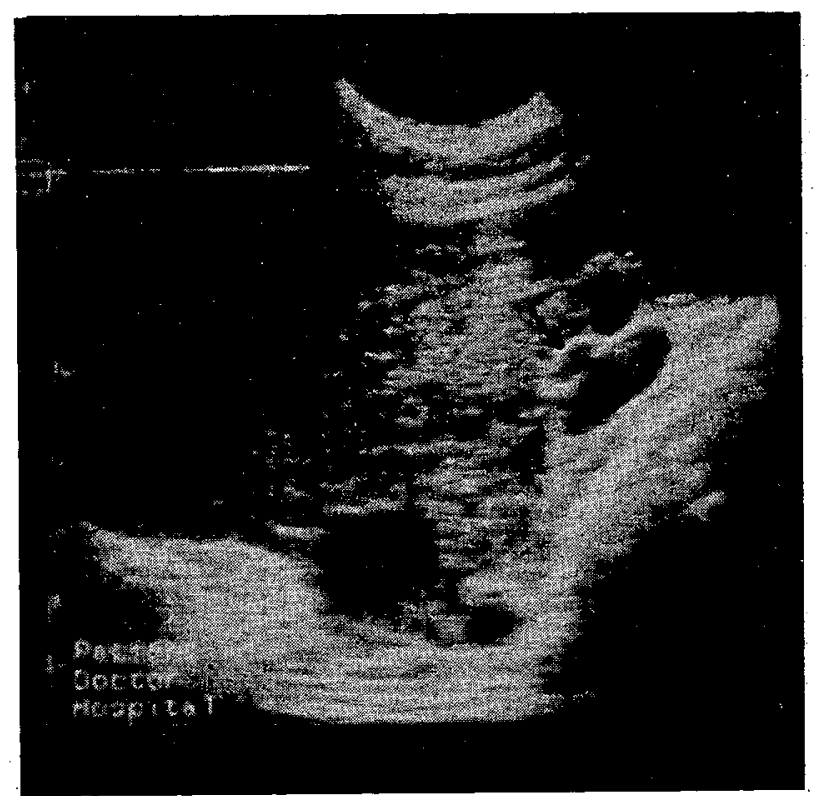

Figure 5. Appearance of a folding in the gallbladder with witl thickening shown by the arrows. Small part of the folding is possible dilated bile duct. Note also that there is a cyst shown by " $\mathrm{C}$ " close to the diaphragm.

Table 1. Numbers of animals with biliary, parenchymal or both lesions, and other ultrasonographic findings, which were observed alone or together.

\begin{tabular}{lcccc}
\hline Lesions & $\begin{array}{c}\text { Biliary } \\
\text { system } \\
(\mathrm{n}=8)\end{array}$ & $\begin{array}{c}\text { Parenchynal } \\
\text { tissue } \\
(\mathrm{n}=17)\end{array}$ & $\begin{array}{c}\text { Biliary+ } \\
\text { Parenchymal } \\
(\mathrm{n}=23)\end{array}$ & $\begin{array}{c}\text { Total } \\
(\mathrm{n}=48)\end{array}$ \\
\hline Hyperechogenicity & - & 10 & 16 & 26 \\
Wall thickening & 6 & - & 19 & 25 \\
Cyst & - & 7 & 10 & 17 \\
Mass & - & 4 & 6 & 10 \\
Folding & 1 & - & 2 & 3 \\
Sedimentation & 1 & - & 2 & 3 \\
Total & 8 & 21 & 55 & 84 \\
\hline
\end{tabular}

The biochemical analyses of the blood serum resulted in that the activities of AST, ALT, ALP and GGT, and the level of glucose, CB, TP, Alb, BUN and $\mathrm{CHO}$ were found to be in normal ranges whereas the activity of $\mathrm{LDH}$ was higher than the normal reference range although there was no significant difference ( $p>0.05$ ) between goats with and without hepatic lesions (Table 2).

\section{Discussion and Conclusion}

Many clinical signs, such as icterus, weight lose, ascites, diarrhoea and abdominal pain, which are regarded not to be pathognomonic, may be present with liver disease $(4,10)$. None of these symptoms were detected in the study presented. Pathologic changes in the liver may include biliary hyperplasia, death of hepatocytes and fibrosis, and they may occur before the symptoms of liver failure develop $(6,8,9)$. 
Table 2. Blood serum biochemical analyses of goats with and without subclinical hepatic lesions diagnosed by ultrasound.

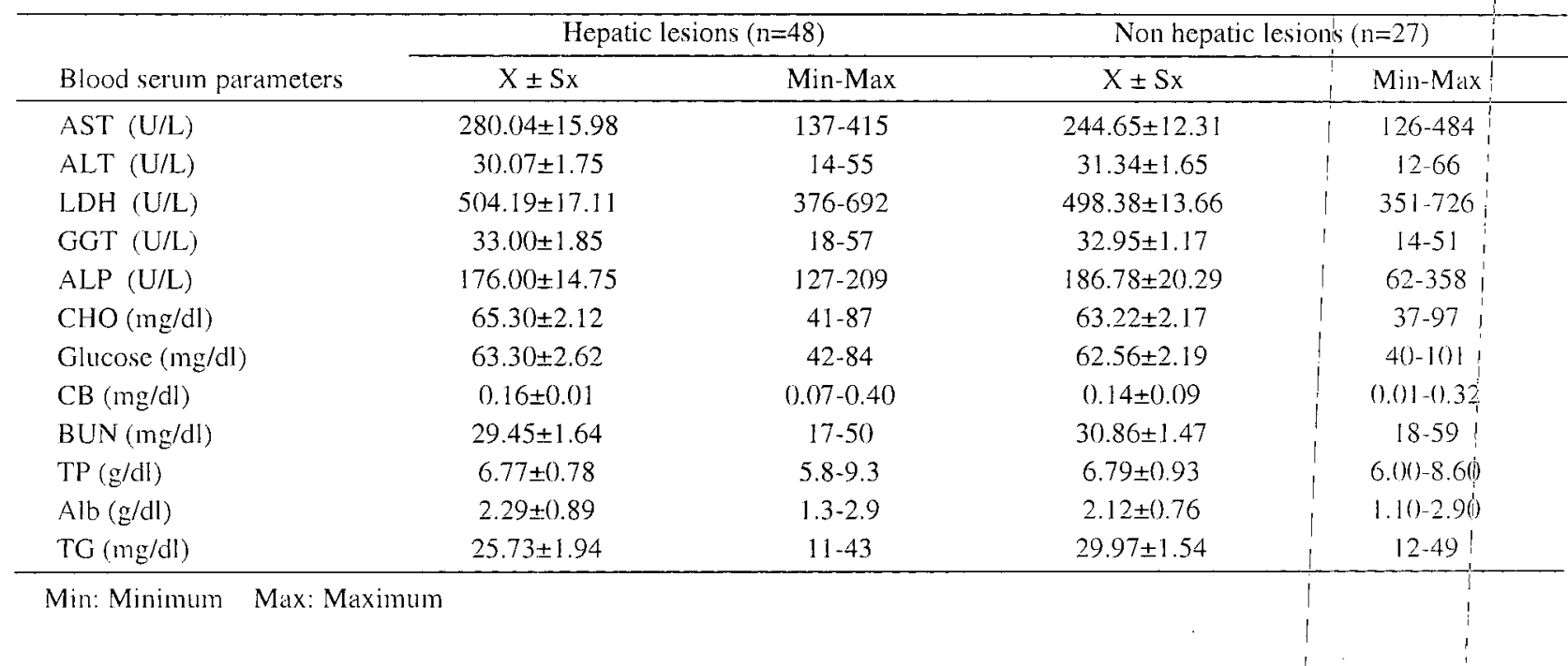

Ultrasound is an important tool in detecting focal liver abnormalities such as cyst, hemorrhage, granuloma and neoplasia because of the uniform background provided by the normal parenchyma. These focal lesions can not be differentiated from each other, because they may look similar in echogenicity, size and appearance on scans $(8,9,12)$. However, cysts might be distinguished from the others. There are two reports supporting this notion that the sensitivity and specificity of ultrasound examination to detect hydatid cysts in goats was $82.1-97.65 \%$ and hepatic cysts are usually detected incidentally without clinical signs $(5,11)$. They showed no clinical signs in animals with 17 hepatic cysts in the study, and they were differentiated from gallbladder by its lack of contraction on ultrasound as researchers reported $(2,3,5,11)$. A mass may appear moderately circumscribed, exceeding the normal liver margin with an echogenicity, which had slightly more-mixed appearance than normal liver. The increases in hepatic echogenicity may be due to fibrosis, dystrophic calcification or cirrhosis $(1,6,8,9)$. No clinical and biochemical abnormalities or ascites were observed in these animals, implying that the echogenic architecture of the liver parenchyma might be due to fibrosis or dystrophic calcification.

The normal gallbladder wall is visualized, the neck of the gallbladder is usually not visible in normal animals though. Thickening of the wall is a nonspecific finding seen sometimes with acute and chronic hepatitis, cholecyslitis, cholangiohepatitis or hypoalbuminemia, less frequently right heart failure, septic conditions, and neoplasia (1,7-9). Thickening of the gallbladder imaged in this study can be possibly resulted from chionic or mild hepatitis or cholecystitis. It should be noted that the liver has a large reserve capacity, and clinical signs and biochemical parameters can occur when the liver function was lost about $75 \%(4,10)$.

In this study, the amount of gallbladder sediment was not found to be pathognomonic. The sediment may be seen in healthy non-fasting animals as well as those with illness such as icterus, chronic hepatitis, fibrosis and calculi $(8,10)$

It is reported that folding of gallbladder observed in this study may be that gallbladder dilated on partially folded on itself $(8,9)$.

In chronic hepatitis, GGT, ALP and LDH increases, and biliary damage and hyperplasia were seen $\mid(4,10)$. In this study, GGT and ALP were found normal levels indicating that liver functional capacitiy was not entirely lost, whereas LDH levels were' higher thàn normal reference range. This increase in $\mathrm{LDH}$ may tesult from another organ damage or disease. In conclusion, results presented here suggest that subclinical liver lesions could be detected commonly with ultrasonographic| evaluation even if they may be clinically normal, and their biochemical parameters are also found to be normal in goats.

\section{References}

1. Biller DS, Kantrowitz B, Miyabayashil T (1992): Ultrasonography of diffuse liver disease. J Vdi Intern Med. 6, 71-76.

2. Blanton RE, Wachira TM, Zeyhle EE, Njoroge EM, Magambo JK, Schantz PM (1998): Oxfendizole treatment for cystic hydatid disease in naturally infected animuls. Antimicrob Agents Chemother, 42, 601-6015. 
3. Dueger EL, Moro PL, Gilman RH (1999): Oxfendazole treatment of sheep with naturally acquired hydatid disease. Antimicrob Agents Chemother, 43, 2263-2267.

4. Kaneko JJ, Harvey JW, Bruss ML (1997): Clinical Biochemistry of Domestic Animals. $5^{\text {th }}$ ed. Academic Press. Philadelphia.

5. Maxson AD, Wachira TM, Zeyhle EE, Fine A, Mwangi TW, Smith G (1996): The use of ultrasound to study the prevalence of hydatid cysts in the right lung and liver of sheep and goats in Turkana, Kenva. Int J Parasitol, 26. 1335-1338.

6. Nyland TG, Hager DA (1985): Sonography of the liver, gallbladder and spleen. Vet Clin North Am Small Anim Pract, 15, 1123-1148.

7. Nyland TG, Hager DA, Herring DS (1989): Sonography of the liver, gallbladder and spleen. Semin Vet Med Surg (Small Anim), 4, 13-31.

8. Nyland TG, Mattoon JS, Wisner ER (1995): Ultrasonography of the Liver. 52-73. In: TG Nyland, JS Mattoon (Eds), Veterinary Diagnostic Ultrasound. WB Saunders Co, Philadelphia.

9. Partington BP, Biller DS (1996): Liver: 105-130. In: RW Green (Ed), Small Animal Ultrasound. Lippincott-Raven, Philadelphia.
10. Pearson EG (1996): Diseases of the Hepatobiliary System. 913-920. In: BP Smith (Ed), Large Animal Internal Medicine. $2^{\text {nd }}$ edition. Mosby, Philadelphia.

11. Sage AM, Wachira TM, Zeyhle EE, Weber EP, Njoroge E, Smith G (1998): Evaluation of diagnostic ultrasound as a mass screening technique for the detection of hydatid cysts in the liver and lung of sheep and goats. Int J Parasitol, 28, 349-353.

12. Singh AK, Behari J (1994): Ultrasound nonlinearit parameter (B/A) in biological tissues. Indian J Exp Biol, 32, 281-283.

13. West HJ (1991): Evaluation of total serum bile acid concentrations for the diagnosis of hepatobiliary disease in cattle. Res Vet Sci, 51, 133-140.

Received 16 April $2002 /$ Accepted 13 May: 2002

\section{Correspondence address:}

Dr. Ramazan Gönenci,

Mustafa Kemal Üniversitesi, Veteriner Fakültesi Cerrahi Anabilim Dall.

31040, Hatay, Türkiye 